\section{Protection of the Fauna and Flora of Africa}

Reference has already been made in NATure to the recent international conference on this subject held in London (Nov. 18, p. 776). At a general meeting of the Society for the Preservation of the Fauna of the Empire on December 4, the president, the Right Hon. the Earl of Onslow, discussed in some detail the convention which has been agreed on as a result of the international conference. Lord Onslow said that in the first place the convention lays down as a principle that it is desirable to establish in all territories if possible national parks or strict natural reserves. A national park is a permanent institution such as the Kruger Park in South Africa, where fauna and flora may be strictly preserved for the benefit of the general public. A strict natural reserve is a similar area but it is devoted purely to scientific purposes, that is to say, it is primarily for the preservation of various species. With reference to the protection of special animals, in the annex to the convention there are two classes: animals the protection of which is of special urgency, and those which do not require such rigorous protection but need a modified form of protection under which they cannot be hunted without a special licence. On the question of trophies, the convention lays down a method of controlling by means of the Customs in each territory the export and import of trophies, trophies meaning heads, horns, tusks, eggs and so forth, in fact anything which is produced by an animal. Certain methods of hunting are prohibited, notably by the use of motor-cars and aircraft. Similarly, poisons or explosives for killing fish are prohibited, and also dazzling lights or nets and pits.

THE convention does not come into force until it has been ratified by four powers, but owing to the proposal of the vice-president of the conference, the Belgian Ambassador, a protocol has been signed which does not need ratification and which binds the contracting parties who have signed it, namely, all the powers represented except, so far, Abyssinia, to call another conference in four years time. This will prevent the question lapsing into oblivion, but it is sincerely to be hoped that before another conference takes place, a substantial portion of the powers that signed the convention will be carrying it into force, so that the experience gained in working may suggest modifications for the conference to discuss. Lord Onslow said that the dedication of national parks has been urged by the Society for the Preservation of the Fauna of the Empire for some time past, and he considered it a matter for congratulation that the British Government has not only adopted the idea but also has taken such strong action as to facilitate a conference being called whereby the present convention was evolved.

\section{River Flow Records}

IT is appropriate that the recent issue of the report of the Research Committee of the British Association on Inland Water Survey should be followed by the publication of a paper on practical river flow measurement such as that presented at the winter meeting of the Institution of Water Engineers on December 1. Capt. W. N. McClean, the secretary of the Research Committee, has for several years past, at his personal charges, instituted and maintained a system of river gauging and measurement in the Ness Basin, Inverness-shire, the results of which have been noticed from time to time in these columns. On December 1 he gave a detailed account of the system in a com. prehensive paper which reviewed the physical and meteorological conditions in the Ness Basin and dealt with the various features of the work carried on by the organisation known as River Flow Records which is directed by himself. The catchment area of the Basin is 692 square miles down to Dochfour Weir, which holds up the level of Loch Ness in order to provide navigable depth in the Caledonian Canal. Loch Ness is roughly 24 miles in length and has a depth exceeding $550 \mathrm{ft}$. over about one half its area of 22 square miles. A regular sway of 31 minutes duration, induced by wind, produces a variation in water level, sometimes amounting to six inches or more, which persists long after the wind has ceased, and is attributable in Capt. McClean's opinion to a pendulum effect maintained by the great depth. The greater part of the flow into the loch comes from the rivers Garry and Moriston, and the gauging of these streams formed the subject of the investigations described in the paper. Details of the apparatus employed and the methods adopted are given in supplementary notes by $\mathrm{Mr}$. H. Chapman, the author's chief assistant.

IN the ensuing discussion, Mr. G. J. Griffiths emphasised the importance of river gauging operations, instancing the precautions thereby enabled to be taken in the Thames basin during the recent period of drought, as a result of which there was no shortage of water supply. He put forward a plea for co-operation between catchment boards and water authorities so that the information obtained might be pooled in the interests of the community. As regards the Thames Valley, the subject is discussed in more detail elsewhere in this issue of NatuRE (p. 869). Prof. S. M. Dixon described apparatus used on the River Severn, which he considered simpler and for that reason preferable to the apparatus illustrated in the paper. The Severn apparatus has been used for velocities up to $5 \mathrm{ft}$. per sec. in depths up to $12 \mathrm{ft}$. The estimated accuracy of the gaugings is to within 3 per cent of error. Other speakers dealt with various aspects of the subject and $\mathrm{Mr}$. o. Borer cited instances of low flows of the Great Ouse- 0.09 cusecs. per thousand acres. Capt. McClean, in his reply to the discussion, said that simpler apparatus had been tried on the Ness Basin Rivers without satisfactory results, and he did not think an estimated ratio of error could be confidently accepted when the recorded values of the meters had themselves to be corrected for positioning.

\section{High-Speed Diesel Engines for Marine Service}

THE history of ship propulsion records many revolutions in types of machinery and their application, and in the plan proposed by Mr. H. R. 
Ricardo in his Thomas Lowe Gray lecture to the Institution of Mechanical Engineers delivered on December 1, marine engineers will see yet another great change. Though he could not make out a case for a Diesel engine of any sort in really large or very fast vessels, Mr. Ricardo urged that for ships up to 6,000 horse-power, the power plants might well consist of a very large number of light high-speed Diesel engines, driving electric generators supplying the current necessary for the propulsion motors and for auxiliary purposes. One of the outstanding features in engineering practice of recent times is the marked success of the high-speed Diesel engine for road transport. During the last two years, some 20,000 engines aggregating more than 2,000,000 horse-power have been put into service on the roads of Europe. These engines range up to 150 horsepower, and 70-80 such engines could easily be installed in groups and tiers for a vessel of 6,000 horse-power. The fuel supply, the circulating water and lubricating oil could be supplied from a central station and engines could be started and stopped from a central control. Mr. Ricardo sees no difficulty in the maintenance of such a plant, for the units could be easily disconnected and hoisted out and the engines overhauled regularly at a shore depot. To overcome the noise difficulty, each unit would be enclosed in a double-walled wooden sound-proof box. 'Thus enclosed, the generating sets will sound like bees on a summer's afternoon, and the solitary engine room clerk will be able to smoke his pipe of peace." Fanciful as the scheme appears to be, it is by no means an impossible one and it would be of interest to see it put to the test.

\section{Slaughter-House Reform}

Prof. J. H. Jones delivered the twelfth annual Benjamin Ward Richardson Memorial lecture on November 30 before the Model Abattoir Society, his subject being slaughter-house reform. He said that slaughtering is at present conducted in small private slaughter-houses or in municipal slaughter-houses. The former are often inefficient inasmuch as the scale of organisation prevents the proper utilisation of by-products and in other ways adds to expenses. There are also serious disadvantages connected with municipal slaughter-houses, as not only are they on too small a scale, but also they are merely a collection of stalls for private butchers. In view of the wastefulness of the present system, the Committee of the Economic Advisory Council on the Slaughtering of Livestock, of which Prof. Jones is a member, has recommended a scheme based on regional monopoly. It has recommended the appointment of a National Slaughter-Houses Board, that is, a statutory non-profit-making body to prepare regional shemes to be operated by regional authorities, which might be either joint boards of local authorities or existing associations prepared to provide their own finances. The regional authority would provide the service of the slaughter of animals and the transport of meat to the centres of retail distribution. It would not itself purchase animals and sell meat; on the other hand, it would purchase and itself work up the by-products. It might appear at first sight to create a new departure by establishing a monopoly of slaughtering within each of the selected regions, but monopoly is already a privilege of the municipal slaughter-houses of Scotland and in a few of them a serious attempt is being made to utilise by-products. The recommendations appear to be in line with modern British development and to provide a scheme which would be both efficient on the technical side and likely to improve the inspection of meat and humane slaughter. The scheme would not apply to the trade in Kosherkilled meat.

\section{International Committee on Intellectual Co-operation}

The report of the International Committee on Intellectual Co-operation on the work of its fifteenth plenary session, which contains extracts from the general report of the director of the International Institute of Intellectual Co-operation, indicates the work done in this field, alike in the service of the various States, of the League of Nations, and of intellectual activities for their own sake, the service of ideas, of the mind. During the year, the Institute has continued to concentrate on the collaboration of qualified experts or competent international committees. Thus, arising out of Prof. Shotwell's proposal, a preliminary inquiry has been commenced on collective security and on the collection of data regarding the progress in various countries towards the encouragement of the study of legal, social and political sciences, which should issue in a scientific contribution to the work of the League. The material required for the publication of a repertory of scientific laboratories has been collected. The committee of experts dealing with the co-ordination of scientific terminology has examined in detail various terms responsible for misunderstanding or controversy between chemists and physicists, and established definitions which will be communicated to the International Unions of Physics and Chemistry and to the International Council of Scientific Unions for final approval. Technical recommendations relating to neologisms have also been formulated and various steps taken towards collaboration between science museums, including the publication of a periodical information bulletin, Scientific Museums, while the inquiry on documentation has been vigorously pursued.

\section{Effect of Economy Cuts in the United States}

A RECEnT article in Industrial and Engineering Chemistry (News Edition, Nov. 10, p. 315) reviews the results of the recent economy cuts in chemical research at Washington. On the whole, the results of the Economy Act have been less devastating than at first threatened. Most bureaux were able to continue on a reduced scale; the danger of dilution of personnel with political nominees has been entirely avoided in the scientific branches; the chief effect has been the dropping of less essential projects, and a retardation of progress, with drastic reductions in only one or two departments. Chemical research is centred mainly in the Department of Agriculture and in the 